\title{
$\diamond$ Hotel Reservation Instructions $\diamond$
}

\section{No Form Needed...You Can Call in or Fax Your Reservation! \\ Have the following information ready when calling to make reservations: \\ 1. Arrival and Departure dates \\ 2. Type of Room - single, double ( 2 people, 1 bed), twin ( 2 people, 2 beds) \\ 3. Names of ALL occupants of room(s) \\ 4. Address or fax number to which confirmation should be sent \\ 5. Credit Card Name, Number, and Expiration Date (for guarantee) \\ DEADLINE FOR RESERVATIONS: \\ JUIY 27, 1996 After this date, we cannot guarantee availability of \\ rooms or rates. \\ Note: If you have any disabilities that require special facilities in your sleeping room, please let the agent know at the time you make your reservation.}

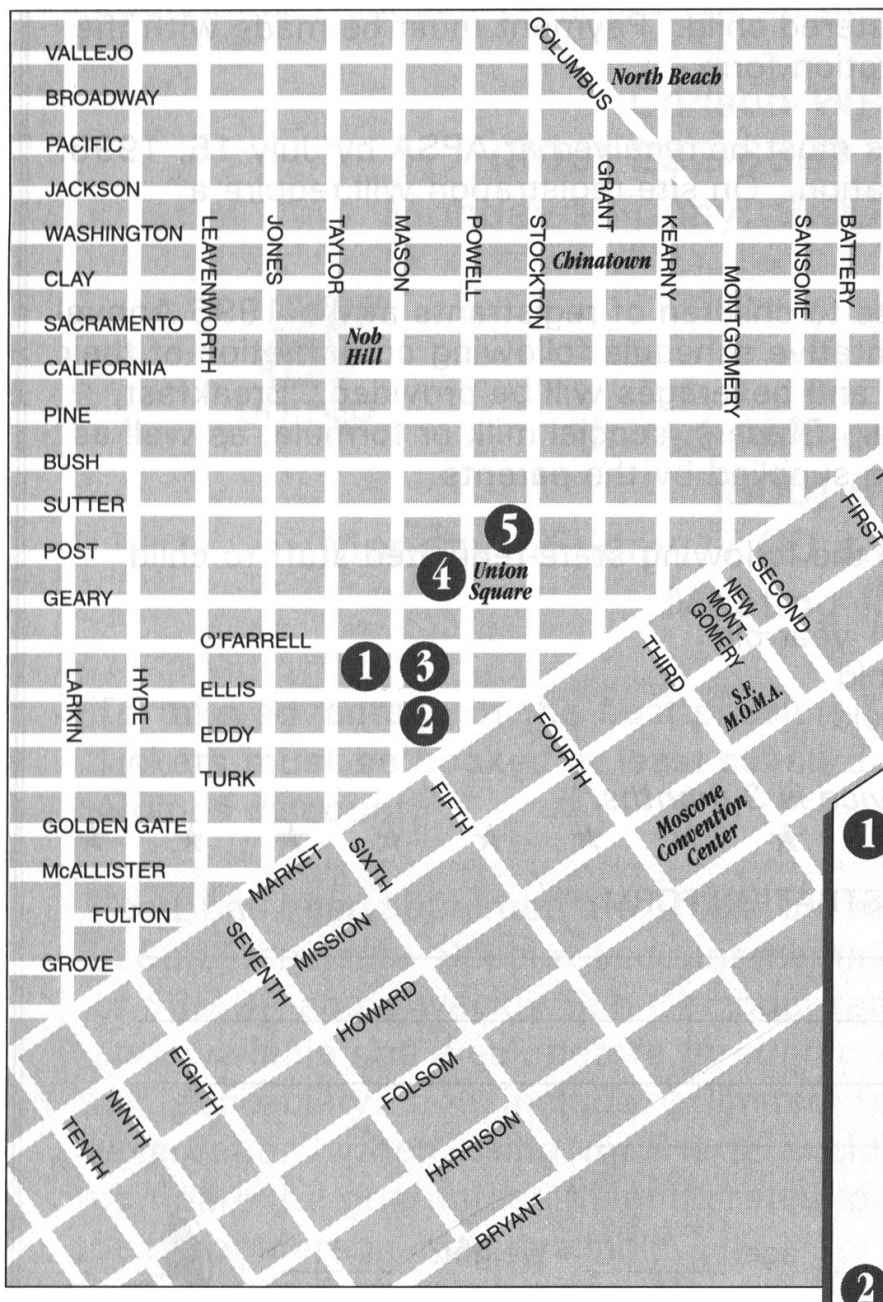

\section{HOTEL INFORMATION AND LOCATIONS}

The San Francisco Hilton and Towers is the headquarters hotel for the 1996 APSA Annual Meeting. Short courses and panels will also be held at the Parc Fifty-Five Hotel, and the Professional Placement Service will be located in the Hotel Nikko.

\section{CONFIRMATIONS}

You will receive a confirmation number when you make your reservation, and a written confirmation by mail.

\section{GUARANTEE}

Your reservation cannot be processed without a credit card guarantee or first night's deposit.

\section{CHANGES/CANCELLATIONS}

Guaranteed reservations must be cancelled by 6:00 p.m. on the day of arrival (by 4:00 p.m. at Hotel Nikko) or you will be charged for one night's room and tax.

\section{RATES}

You must be an APSA member to obtain discounted room rates at the San Francisco Hilton and Towers. If you would like member rates and are not currently an APSA member, submit your membership application to APSA concurrently as you secure your room reservation.

\section{HOTELS}

1 The San Francisco Hilton and Towers 3330 'Farrell Street (Bordered by Ellis, Mason, Taylor Streets)

Member Rates: $\$ 89$ Single $/ \$ 112$ Double Non Member Rates: \$195 Single/\$215 Double

(415) 771-1400 (415) 923-5075 fax

Headquarters botel ideally located steps from Union Square, cable cars and theatres; luxury property occupies a full city block with restaurants, shops, live entertainment, bealth club, sauna, beated outdoor pool.

(2) The Parc Fifty-Five Hotel 55 Cyril Magnin (Bordered by Ellis, Mason Streets) Member Rates: \$89 Single/\$112 Double Non Member Rates: \$155 Single/Double

(800) 338-1338 or (415) 392-8000

Luxury property with panoramic views of the City; two blocks from Union Square; across the street from SF Hilton; restaurants, bealth club.
3 Hotel Nikko San Francisco 22 Mason Street (at 0'Farrell Street) Member Rates: \$93 Single/\$113 Double Non Member Rates: \$179 Single/Double (415) 394-1111 Luxury botel with dramatic public space; glass enclosed pool and fitness center, authentic Japanese and California cuisine

4 Westin St. Francis Hotel 335 Powell Street, Union Square Member Rates: \$89 Single/\$112 Double Non Member Rates: $\$ 165$ Single/Double (415) 397-7000

Elegant world-famous hotel on Union Square; charming rooms of varying sizes, restaurants, fitness center, shopping arcade.

5) Grand Hyatt San Francisco 345 Stockton Street (on Union Square) Member Rates: \$89 Single/\$112 Double Non Member Rates: \$220 Single/\$245 Double (415) 398-1234

Newly-remodeled rooms with balconies, city and bay views; Outdoor deli and restaurants, bealth club. 